\title{
Aufgeklärte Sozietäten, Literatur und Wissenschaft in Mitteleuropa. By Dieter Breuer, Gábor Tüskés and, Réka Lengyel.
} Berlin-Boston: De Gruyter, 2019. 567 pp.

\section{Gábor Förköli}

Humanism in East Central Europe Research Group, Institute of Hungarian Literature and Cultural Studies, Faculty of Humanities, Eötvös Loránd University, H-1088 Budapest, Múzeum krt. 4/A, Hungary; forkoli.gabor@btk.elte.hu

The volume edited by Dieter Breuer and Gábor Tüskés with the cooperation of Réka Lengyel brings together the papers presented at the international conference with the same title held at the Hungarian Academy of Sciences and in the Hungarian National Museum on 11th-15 $5^{\text {th }}$ October 2017. Necessarily, the studies, written in German, in English and in French, represent the heterogeneity of the researchers' personal choices and interests. Nevertheless, the articles approach their common topic, the scientific societies of eighteenth-century Central Europe, from the angle of two, deeply interconnected main subjects: the typology of scientific societies and the sociability in human nature.

As for the taxonomy of scholarly groups or cooperation, the potential aspects are numerous. For instance, the common linguistic program and the use of classical Latin as a vehicle of knowledge are pivotal to understand what the term Republic of Letters means, whereas the categories of secrecy or publicity, of conformism or heterodoxy, enable us to distinguish an institutionalized scientific cooperation from freemasonry or the Rosicrucian movement; the latter constitute central subjects in the volume. Helmut Reinalter's introductory study proposes five categories: academies, patriotic societies, reading societies (Lesegesellschaft), secret societies and salons. However, several articles adopt the typology shared by Françoise Waquet and Steffen Martus, who both distinguish the term academy from the concept of society. In the first instance, Emese Egyed, Olga Penke and Béla Hegedüs exploit this dichotomy in their papers. According to the literature, societies are primarily linked to a protestant political and cultural milieu, they are cultivated by amateurs, i.e. scholars who are not paid for their scientific work, and they are private and independent from the state or any other form of central authority. Good examples of this form of scientific cooperation are the Royal Society of England and the societies of the Holy Roman Empire, which cultivated the German language. 
In contrast, academies are rooted in Catholic civilizations, they are professional (the members are paid), and they depend on the state or some sort of central authority. The perfect archetype of this kind of cooperation is the French Academy. It is in that sense that Béla Hegedüs, in his article about the relationship between belles-lettres and schöne Wissenschaften, uses the dichotomy between Societas and Academia. But, as he argues, the Society of Pressburg (Pressburgische Gesellschaft), turns out to be hardly distinguishable from a secret society or a masonic lodge. Olga Penke, discussing the reform of the Hungarian language, challenges this taxonomy too. Although this reform was initiated at the end of the eighteenth century by amateurs (unpaid intellectuals) and mostly by protestants, one of the models of the movement was the French Academy. Penki illustrates her thesis with the reports about Richelieu's Academy which were published in Hungarian in the review Mindenes Gyüjtemény (Universal Collection), edited by József Péczeli in Komárom.

Other articles help to refine this widely accepted and operational typology by emphasizing the eventual delays in historical progress. Some tendencies simply arrived in East-Central-Europe later than in the West, as attested by the study by Barbara Mahlmann-Bauer, who states that the Hungarian Hebraist György Kalmár was viewed as out of date and, what is more, as an enthusiastic cabbalist by his Western colleagues. Similarly, Andreas Erb, who discusses the German societies for the defence and illustration of the vernacular language, concludes that when societies of this kind reached the Habsburg Monarchy, they had already passed their apogee in the Holy Roman Empire, and their glory had been overshadowed by a new model of scientific cooperation, which was freemasonry. Finally, Ferenc Tóth detects the coexistence of a modern academy and of the more and more anachronistic knight academy (Ritterakamie; académie équestre) in the intellectual circle of Stanislas Leszczynski, king of Poland exiled to Lorraine. In conclusion, the studies in this volume implicitly suggest that any typology of scientific organizations must take into account what Koselleck called non-contemporaneous contemporality.

The other common thread of many papers is the concept of sociability, often discussed in literature in a (pre-)Enlightenment context. Is the friendly nature of human beings rooted in social conventions and in self-interest, or can it be traced back to the elementary instincts of the heart: is it based on sensibility? The theory of this problematic is scrutinized by József Simon in his study on György Bessenyei, a leading figure of the Hungarian Enlightenment. Discussing the Rousseauian problem of society, Simon distinguishes Gesellschaft, impregnated self-alienated moral, from Sozietät, built on sensibility, on friendship. The study investigates the notion of natural law in Bessenyei's work in order to find out which one is the key to recognize what nature demands from human beings according to the author: heart or reason. Gyula Laczházi discusses the same conflict between natural and alienated morality using the example of a work of fiction, Ádám Pálóczi Horváth's novel Disclosed Secret about masonic 
initiation. In contrast to corrupt society, freemasonry, according to the optimistic narratives, would be an ideal community founded on mutual aid, personal merit and freedom, a "Socratic society", as described in an apologetic document from 1738, analyzed by Andreas Önnerfors in his study. This utopian exigence can be observed in the case of the lodge of strict observance in Prague, discussed by Reinhard Markner in the volume: the term utopia is justified by the fact that freemasons in Prague considered their order as a return to an idealistic past, which was the age of the Templars.

As in the case of the taxonomy of scientific organizations, some articles challenge this optimistic vision as well, no matter how useful it is generally. Franz M. Eybl's article about the critical reception of Lessing's Laokoon in Christian Adolf Klotz's correspondence presents the transformation of the Republic of Letters, based on mutual solidarity, into a modern critical publicity. The less amicable tone of this new type of criticism enables us to question the linearity of the progress toward a cult of sensibility in the eighteenth century. In this respect, the article by Marian Füssel on the Vienna masonic lodge "To the True Concord" ("Zur Wahren Eintracht") is also very instructive. Discussing diverse forms of cultural transfers, like journeys, translations, contacts with other lodges and correspondence, the author states that the concept of the masonic lodge can indeed be interpreted as a cultural contact zone. She illustrates this thesis with the example of the famous Angelo Soliman, probably the first documented freemason of African origin, whose rich culture was appreciated in intellectual circles in Vienna. However, Füssel is forced to conclude that masonic lodges were not always perfectly inclusive: whereas confessional differences had almost no place in the Vienna lodge, social distance could awaken certain tensions, given that the lodge in question was seen as a meeting point of an elite which regarded with suspicion those members who were originally craftsmen or intellectuals with no noble ancestry (Honoratior). Moreover, the aristocratic character of this lodge is confirmed in the volume by Olga Ganasztói's study, which discusses its influence on Hungarian magnates.

As we can see, a large part of the papers in the volume contribute to the analysis of the epistemological, anthropological and socio-psychological motives for creating scientific societies. Other topics are present as well, which cannot easily be integrated into the above mentioned two main axes. Some papers discuss philosophical subjects: Endre Kiss, for instance, dedicates his study to the question addressed by the Berlin Academy of Sciences in 1761: can the basic metaphysical truths be proven with geometric certainty? Certain articles discuss natural law or law in general: beside József Simon, Ivo Cerman must be mentioned, who presents Christian Wolff's teaching on state law. Dieter Breuer, who is also an editor of the book, analyses the ideal ruler of the Enlightenment in Eulogius Schneider's funeral eulogy of Emperor Joseph II. Some papers open a perspective toward the role of scientific communities in the linguistic reforms, by studying the normative function in the dictionaries of the age, like the texts of Margit Kiss and Eszter Cs. Herger, who describe a nineteenth-century Hungarian project for harmonizing the terminology of law with a juridical dictionary. 
Others deal with diverse aspects of freemasonry. Róbert Péter argues for a coexistence of an enthusiastic attitude toward esoterism with a more critical one amongst Hungarian freemasons. Piroska Balogh details the constitution of the Draskovics Observance in freemasonry, named after its Croatian-Hungarian founder Count János Draskovics; Annamária Biró and Thomas Şindilariu discuss Transylvanian freemasonry, whereas Roland Martin Hanke dedicates his paper to the Antimasonic Society in Germany and in Denmark which was not an antagonist, but rather an alternative to freemasonry: it accepted women in its ranks, for example. Masonic themes are emphasized in the case of literary works as well: in Ferenc Kazinczy's writings by Márton Szilágyi and in Ádám Pálóczi Horváth’s by István Csörsz Rumen. The heritage of the lodges appears also in freemasonic archives and collections in the domains of science, letters or art, which are illustrated by the case studies of Réka Lengyel, Anna Tüskés and Gábor Tüskés. Gábor Tüskés's paper has first of all the merit of detecting the presence of masonic symbolism in the collection of a Hungarian aristocrat, Mihály Viczay. The article, which is rich in data and in visual materials, makes a contribution to art history, taking a fresh look at often misunderstood or underestimated art works. Finally, we should mention a notion which is omnipresent in the volume, though less subject to a theoretic reflection: network. As a system of intellectual contacts, the concept is key to the analysis of scientific cooperation in Andrea Seidler's paper about the polymath Ignaz von Born as the editor of the Vienna review Physikalische Arbeiten, while Etelka Dolcsecz uses the notion of network to reconstruct the potential masonic acquaintances of Ferenc Verseghy, whose adherence to freemasonry remains unproven because of lack of data.

Despite the inevitable contingencies of conference proceedings, the volume can serve as a starting point or even as a bibliographic source for research on academies, scientific societies and freemasonry in the eighteenth century. It is a pity that several minor errors make it more difficult to use the book. The inconsistent use of a proper name can be a source of confusion for a non-Hungarian scholar: while Gyula Laczházi uses the form Ádám Horváth, Rumen István Csörsz writes Ádám Pálóczi Horváth, although they are the same person. The name of the eminent French historian Françoise Waquet is spelled incorrectly; German quotation marks and apostrophes are used in French articles, and there is even a mistranslation from Latin in the paper by Thomas Şindilariu, who confuses the verb servio with servo: "fidem genusque servabo ([meinem] Glauben und [meinem] Stamm/Geschlecht/Art werde/will ich dienen" (p. 471). Careful checking by the editors could have prevented these annoying mistakes.

https://orcid.org/0000-0001-8653-9792

(c) 2021 The Author(s). This is an open-access article distributed under the terms of the Creative Commons Attribution-NonCommercial 4.0 International License. 